\title{
PENGARUH KEPEMIMPINAN, BUDAYA ORGANISASI DAN MOTIVASI TERHADAP KINERJA GURU SMP NEGERI SE- KECAMATAN CIASEM KABUPATEN SUBANG
}

\author{
Pratiwi Lesmanawati \\ Universitas Singaperbangsa Karawang \\ email : pratiwi241070@gmail.com
}

\begin{abstract}
The research was conducted in Ciasem Subdistrict Subang District West Java on all SMP Negeri which were in Ciasem Subditrict i.e : SMPN I, SMPN 2, SMPN 3 and SMPN 4.

The aim of this research was to analysis of Management, Organization Culture and Motivation on the Teacher job description of SMP Negeri in Ciasem Subdistrict, Subang District West Java.

The result showed that the leader of Management, Organization culture, Motivation and Teacher Job description were well. The individual correlation refered that the correlation of Management and Organization Culture gave of correlation coefficient value (r) of 0.603 and they refered strong correlation to direction and positive. It mean the increase of Management would increase Organization Culture. It in stead of that. The correlation of Organization Culture and Motivation gave correlation coefficient value (r) of 0,632 and they refered strong correlation to direction and positive. It mean the increase of Organization culture would increase Motivation. It in stead that. The correlation of Management and Motivation gave correlation coefficient value (r) of 0.514 and they refered strong correlation to direction and positive. It mean the increase of Management would increase Motivation. It in stead that. In this research gave influence Management, Organization culture and Motivation on Teacher job description of $23,4 \%, 24,5 \%$ and $27,4 \%$ respectively. They refered that the influence of Motivation on Teacher Job description was higher in contribution than Managemet and Organization Culture. In simultaneous correlation of Management, Organization Culture, and Motivation were significance influence on Teacher job description. They gave R Square of 75,3\%, They refered Teacher job description was influenced by Mangement, Orgnanization Culture and Motivation. While remainder of $24.7 \%$ were influenced by other variables which no test in this research.
\end{abstract}

\section{Key words : management, organization culture, motivation.}

\section{Latar Belakang Penelitian}

Pendidikan merupakan faktor utama pembentukan pribadi umat manusia, baikburuknya pribadi manusia salah satunya ditentukan oleh pendidikan. Demikian pula halnya daya saing suatu bangsa salah satunya dibentuk oleh pendidikan. Dalam menghadapi era globalisasi dunia yang ditandai oleh perkembangan teknologi yang sangat cepat disegala bidang, khususnya bidang Pendidikan. Pemerintah terus berupaya melakukan berbagai perubahan dan pembaharuan sistem pendidikan. Oleh itu sistem pendidikan yang baik, maka 
akan diharapkan muncul generasi yang berkualitas dan mampu menyesuaikan diri untuk hidup bermasyarakat, berbangsa dan bernegara.

Rendahnya kualitas sumber daya manusia merupakan masalah mendasar yang dapat menghambat pembangunan dan perkembangan ekonomi nasional. Penataan sumber daya manusia perlu diupayakan secara bertahap dan berkesinambungan melalui sistem pendidikan yang berkualitas, baik pada jalur pendidikan formal, informal maupun nonformal, mulai dari pendidikan dasar sampai dengan pendidikan tinggi.

Salah satu permasalahan pendidikan yang dihadapi oleh bangsa Indonesia adalah rendahnya mutu pendidikan pada setiap jenjang dan satuan pendidikan, khususnya pendidikan dasar dan menengah. Berbagai usaha telah dilakukan untuk meningkatkan mutu pendidikan, antara lain melalui berbagai pelatihan dan peningkatan kualitas guru, pengadaaan buku dan alat pelajaran/alat peraga, perbaikan sarana dan prasarana, serta peningkatan-mutu manajemen sekolah. Namun berbagai indikator peningkatan mutu pendidikan belum menunjukkan peningkatan yang merata. Banyak komponen yang turut mempengaruhi rendahnya mutu atau kualitas pendidikan, apabila pendidikan dilihat sebagai suatu sistem, maka faktor yang turut mempengaruhi mutu dan kualitas pendidikan tersebut meliputi input mentah (siswa), lingkungan intruksional, proses pendidikan dan keluaran atau kelulusan pendidikan. Salah satu komponen yang menjadi tolak ukur keberhasilan sekolah adalah kinerja guru.

Kepemimpinan yang diterapkan akan mempengaruhi perilaku bawahan dan terciptanya suasana iklim kerja, apakah itu mengarah kepada hal yang positif ataupun sebaliknya. Budaya Organisasi yang diterapkan oleh kepala sekolah yang kurang berwibawaan dan tidak tegas menerapkan budaya organisasi terhadap bawahan akanmenciptakan suasana iklim pendidikan yang tidak nyaman, dan prosespembelajaran akan berjalan seadanya. Sedangkan sikap kepala sekolah yangberwibawa, tegas, adil dan perhatian terhadap bawahan atau guru dan siswa, akan menciptakan suasana pendidikan yang harmonis dan nyaman dalam pembelajaran bahkan akan terciptanya suatu prestasi pendidikan.

Motivasi yang kuat sekali akan mendorong seseorang untuk berhasil, mereka bergulat untukmencapai prestasi pribadi bukan semata-mata untuk ganjaran atas sukses yang dicapai. Mereka mempunyai hasrat untuk melakukan sesuatu dengan lebih baik atau lebih efisien dari pada yang telah dilakukan sebelumnya. Para peraih prestasi tinggi tidak menyukai keberhasilan karena kebetulan, akan tetap mereka lebih menyukai tantangan untuk menyelesaikan suatu masalah dan menerima dengan baik tanggungjawab pribadi untuk mencapai sukses atau kegagalan, bukannya mengandalkan hasil yang dicapai pada faktor kebetulan atau peluang yang diciptakan dari tindakan orang-orang lain, mereka bahkan cenderung menghindari tugas-tugas yang terlalu mudah atau sebaliknya terlalu sukar, dengan kata lain, mereka menyukai tugas-tugas yang tingkat kesulitannya menengah.

Produktivitas kinerja guru akan baik, apabila didukung oleh suasana budaya sekolah yang nyaman, kondusif dan kompetitif. Sehingga mendorong guru lebih bergairah, berdisiplin dan memberikan kinerja yang baik dalam proses belajar/mengajar. Apabila suasana iklim sekolah tidak mendukung, misalnya gaya kepemimpinan kepala sekolah bersikap acuh tak acuh terhadap guru yang rajin ataumalas, sering mangkir atau datang terlambat, serta mengurangi jam mengajar 
kepada siswa, hal ini akan berdampak pada kinerja guru yang menurun.

Penciptaan tersebut akan terealisasi bila kepemimpinan kepala sekolah yang diterapkan tepat dan cocok untuk iklim di sekolah. Sehingga diharapkan dapat menciptakan suasana kerja yang nyaman di sekolah sehingga sikap guru, kedisiplinan guru dan kinerja guru akan tampak baik dan positif untuk kegiatanproses pembelajaran di sekolah. Sebagaimana fenomena di atas penulis tertarik untuk meneliti dengan judul Pengaruh Kepemimpinan, Budaya Organisasi dan Motivasi terhadap Kinerja Guru SMP Negeri Se-Kecamatan Ciasem Kabupaten Subang.

\section{Perumusan Masalah}

Berdasarkan uraian di atas, maka masalah dalam penelitian ini dirumuskan sebagai berikut:

1. Bagaimana kepemimpinan kepala sekolah, budaya organisasi dan motivasi guru?

2. Seberapa besar korelasi antara kepemimpinan kepala sekolah dengan budaya organisasi, budaya organisasi dengan motivasi dan kepemimpinan kepala sekolah dengan motivasi guru?

3. Seberapa besar pengaruh parsial antara kepemimpinan kepala sekolah, budaya organisasi dan motivasi terhadap kinerja guru?

4. Seberapa besar pengaruh simultan antara kepemimpinan, budaya organisasi dan motivasi terhadap kinerja guru?

\section{Tujuan Penelitian}

Berdasarkan perumusan masalah di atas, tujuan dari penelitian ini adalah:

1. Menganalisis kepemimpinan kepala sekolah, budaya organisasi dan motivasi kerja guru

2. Menganalisis korelasi antara kepemimpinan kepala sekolah dengan budaya organisasi, budaya organisasi dengan motivasi dan kepemimpinan kepala sekolah dengan motivasi guru?

3. Menganalisis pengaruh parsial antara kepemimpinan kepala sekolah, budaya organisasi dan motivasi terhadap kinerja guru

4. Menganalisis pengaruh Simultan antara kepemimpinan, budaya organisasi dan motivasi terhadap kinerja guru?

\section{Kepemimpinan Kepala Sekolah}

Secara sederhana kepala sekolah dapat didefinisikan sebagai "seorang tenaga fungsional atau guru yang diberi tugas tambahan untuk memimpin suatu sekolah" dimana diselenggarakan proses belajar mengajar atau tempat dimana terjadi interaksi antara guru yang memberi pelajaran dan murid yang menerima pelajaran. Kepala Sekolah yang berhasil apabila mereka memahami keberadaan sekolah sebagai organisasi yang kompleks dan unik, serta mampu melaksanakan peranan kepala sekolah sebagai seseorang yang diberi tanggungjawab untuk memimpin sekolah menurut Wahjosumidjo (2010: 81).

Kepemimpinan dalam organisasi sekolah secara umum sama. Kepala Sekolah adalah pemimpin sekaligus manajer yang harus mengatur, memberi perintah sekaligus mengayomi bawahannya yaitu para guru dan menyelesaikan masalah-masalah yang timbul. Wahjosumidjo (2002: 83) mengartikan bahwa: 
"Kepala sekolah adalah seorang tenaga fungsional guru yang diberi tugas untuk memimpin suatu sekolah dimana diselenggarakan proses belajar mengajar atau tempat dimana terjadi interaksi antara guru yang memberi pelajaran dan murid yang menerima pelajaran."

Sementara Rahman dkk (2006 : 106) mengungkapkan bahwa "Kepala sekolah adalah seorang guru (Jabatan fungsional) yang diangkat untuk menduduki jabatan structural (kepala sekolah) di sekolah.

Keberhasilan sekolah ditentukan oleh bebagai factor diantaranya kepemimpinan kepala sekolah. Menurut Mulyasana (2009: 98) "Kepala sekolah sedikitnya mempunyai peran dan fungsi sebagai Edukator, Manajer, Adminstrator, Supervisor, Leader, Inovatir dan Motivator (EMASLIM)" oleh Karena itu kepemimpinan kepala sekolah akan sangat berpengaruh terhadap kemajuan dan keberhasilan sebuah sekolah untuk mencapai tujuan.

Adapun pengertian kepemimpinan kepala sekolah menurut Rusyan (2000) adalah kepemimpinan kepala sekolah memberikan motivasi kerja bagi peningkatan produktivitas kerja guru dan hasil belajar siswa. Kepemimpinan kepala sekolah harus benar-benar dapat dipertanggungjawabkan, karena tanggung jawab kepala sekolah sangat penting dan menentukan tinggi rendahnya hasil belajar para siswa, juga produktivitas dan semangat kerja guru tergantung kepala sekolah dalam arti sampai sejauh mana kepala sekolah mampu menciptakan kegairahan kerja dan sejauh mana kepala sekolah mampu mendorong bawahannya untuk bekerja sesuai dengan kebijaksanaan dan program yang telah digariskan sehingga produktivitas kerja guru tinggi dan hasil belajar siswa meningkat.

Berdasarkan beberapa pengertian di atas dapat disimpulkan bahwa kepala sekolah adalah seorang guru yang mempunyai kemampuan untuk memimpin dan memanajemen segala sumber daya yang ada pada suatu sekolah sehingga dapat diberdayagunakan secara maksimal untuk mencapai tujuan bersama

\section{Budaya Organisasi}

Budaya organisasi merupakan pondasi bagi suatu organisasi. Efektifitas suatu organisasi akan berkembang dengan menciptakan budaya yang kuat agar dapat digunakan untuk mencapai tujuan organisasi, sebab budaya yang kuat memiliki ciri khas tertentu sehingga dapat menarik individu untuk bergabung kedalam organisasi tersebut. Perilaku perilaku individu dalam suatu organisasi sangat mempengaruhi budaya organisasi itu sendiri sehingga semakin banyak individu memegang teguh budaya yang sudah terbentuk maka budaya tersebut akan semakin kuat demikian pula sebaliknya.

Mangkunegara (2008: 113) mengatakan yang dimaksud dengan budaya organisasi adalah seperangkat asumsi atau sistem keyakinan, nilai nilai dan norma-norma yang dikembangkan dalam organisasi yang dijadikan pedoman tingkah laku bagi anggota anggotanya untuk mengatasi masalah adaptasi ekternal dan integritas ekternal. Pemahaman budaya organisasi dapat diartikan sebagai seperangkat norma-norma yang dapat dijadikan aturan didalam organisasi untuk diikuti oleh perilaku induvidu yang berada dalam organisasi tersebut.

Robbins dalam bukunya perilaku organisasi (2008: 256) adalah: "Organization is a system of shared meaning held by members that dist inguishes the organization from other organization. This system of shared meaning is, on closer examination, a set of key characteristics that the organization values" 
("Budaya organisasi adalah sebuah system pemaknaan bersama yang dibentuk oleh warganya yang sekaligus menjadi pembeda dengan organisasi lain. Sistem pemaknaan bersama merupakan seperangkat karakter kunci dari nilai-nilai organisasi").

Berdasarkan pemahaman tersebut, budaya organisasi dapat diartikan sebagai seperangkat norma norma / aturan menjadi ciri khas suatu organisasi dijadikan acuan berperilaku dan bersikap didalam organisasi untuk diikuti oleh perilaku induvidu yang berada dalam organisasi tersebut.

\section{Motivasi}

Dalam menjalankan kegiatan organisasi, seorang manajer akan selalu dituntut untuk agar dapat mempengaruhi bawahannya melaksanakan tugas sesuai yang diperintahkan dengan perasaan nyaman, tidak tertekan dan dalam suasana kegairahan yang tinggi, agar terpenuhi segala kebutuhannya. Semakin terpenuhi kebutuhanya akan semakin tinggi motivasi yang dia peroleh.

Suparno Eko Widodo (2015: 187) mendefinisikan bahwa motivasi adalah kekuatan yang ada dalam seseorang yang mendorong perilakunya untuk melakukan tindakan. Robbins dan Coulter (2004) berpendapat motivasi merupakan ketersediaan mengeluarkan tingkat upaya yang tinggi untuk tujuan organisasi yang dikondisikan oleh kemampuan upaya itu dalam memenuhi beberapa kebutuhan induvidu tertentu. Berelson dan steiner dalam Darodjat (2015: 187) berpendapat "A Motive is an inner state that energizes, activitiesor move, and that direct or channels behavior to ward goals" (Motivasi adalah daya dorong yang datang dari dalam diri seseorang yang mengarahkan perilaku untuk mencapai suatu tujuan).

Dari pemahaman diatas dapat disimpulkan, Motivasi adalah serangkaian sikap dan nilai yang mempengaruhi individu untuk mencapai hal yang spesifiksesuai agar tujuan individu tujuan hidupnya tercapai. Sikap dan nilai tersebut merupakan suatu yang invisible yang memberikan kekuatan untuk mendorong induvidu bertingkah laku dalam mencapai tujuan.

\section{Kinerja}

Menurut Robert Becal dalam Wibowo (2010: 8) menjelaskan bahwa manajemen kinerja adalah suatu proses komunikasi yang terus menerus dilakukan dalam kerangka kerjasama antara seorang karyawan dan atasan langsungnya, yang melibatkan penetapan penghargaan. Manajemen kinerja adalah perkakas komplit yang digunakan dengan tujuan mengoptimalkan keberhasilan setiap karyawan, kelompok kerja, manajer dan organisasi tersebut.

Farstino Cardoso Gomes dalam Mangkunegara (2009: 9) mengemukakan definisi kinerja karyawan sebagai "ungkapan seperti output, efesien serta efektivitas yang sering dihubungkan dengan produktivitas".

Berdasarkan pengertian diatas, penulis dapat disimpulkan yang di maksud dengan kinerja adalah Prestasi kerja yang dicapai oleh seorang pegawai dalam mengerjakan tugasnya yang telah ditetapkan /diberikan oleh pemimpinsesuai dengan keahliannya.

Menurut Undang-Undang Republik Indonesia No. 14 Tahun 2005 tentang Guru dan Dosen Bab I Pasal I, bahwa yang dimaksud guru adalah pendidik profesional dengan tugas latih, menilai dan mengevaluasi peserta didik pada 
pendidikan usia dini jalur pendidikan formal, pendidikan dasar dan menengah. Selanjutnya yang dimaksud profesional adalah pekerjaan atau kegiatan yang dilakukan oleh seseorang dan menjadi sumber penghasilan kehidupan yang memenuhi standar mutu atau norma tertentu serta memerlukan pendidikan profesi.

\section{Dimensi Kinerja Guru}

Sistem penilaian unjuk kerja memerlukan standar yang berfungsi sebagai tolak ukur unjuk kerja. Agar efektif, maka standar yang digunakan harus berkaitan dengan hasil yang diharapkan dari suatu pekerjaan. Memperhatikan peran sentral guru, maka kinerja guru dapat dilihat dari kuantitas dan kualitas guru dalam melangsungkan kegiatan belajar mengajar (KBM) yang tercermin dari aktualisasi penguasaan kompetensi profesi guru dalam mengajar. Usman (2000: 14) menyatakan bahwa kompetensi guru merupakan kemampuan dan kewenangan guru dalam melaksanakan profesi keguruarnnya. Seseorang dinyatakan kompetensi pada bidang tertentu jika ia menguasai kecakapan kerja atau keahlian yang selaras dengan tuntutan bidang kerja. Kompetensi keahlian yang dimaksud adalah mampu untuk Rencana pengajaran, Melakukan prosedur mengajar dan membimbing, mengarahkan, melatih, menilai dan mengevalusi.

\section{Metode yang di gunakan}

Metode penelitian yang akan digunakan pada penelitian ini adalah metode kuantitatif dengan pendekatan analisis deskriptif dan analisis verifikatif.

\section{Disain Penelitian}

Metode analisis deskriptif, yaitu penelitian terhadap masalah-masalah berupa fakta-fakta saat ini dari suatu populasi. Metode analisis deskripsi merupakan metode penelitian yang akan penulis lakukan. Sedangkan tujuan dari penelitian deskriptif adalah untuk menguji hipotesis atau menjawab pertanyaan yang berkaitan dengan current status dari subyek yang diteliti dan menggunakan metode kuantitatif untuk mencari pengaruh antar variabel yang diteliti.

Pemilihan metode ini didasarkan pada keinginan peneliti untuk mendapatkan gambaran mengenai kepemimpinan kepala sekolah, budaya organisasi, motivasi dan kinerja guru SMP Negeri Se-Kecamatan Ciasem Kabupaten Bandung Barat, serta pengaruhnya baik langsung maupun tidak langsung dari variabel-variabel penelitian yang ditetapkan.

\section{Sumber Data}

Data yang dipakai dalam penelitian ini adalah data primer bersumber dari survey ke lapangan melalui wawancara, observasi, dan kuesioner langsung kepada guru guru PNS yang berada di SMP Negeri 1 Ciasem, SMP Negeri 2 Ciasem, SMP Negeri 3 Ciasem dan SMP Negeri 4 Ciasem di kecamatan Ciasem Kabupaten Subang.

\section{Teknik Pengumpulan Data}

Metode penelitian menggunakan sumber data primer yang bersumber dari survei ke lapangan melalui teknik yang digunakan untuk mengumpulkan data dalam penelitian ini dengan menggunakan kuesioner, wawancara dan observasi. 


\section{Uji Keabsahan data}

Kuntadi (2002: 57) berpendapat agar hasil penelitian valid dan reliabel, butir-butir pertanyaan dalam kuesioner perlu dilakukan uji validitas dan reliabilitas. Uji validitas dan reliabilitas instrument ini digunakan untuk menghindari adanya bias penelitian akibat subyektifitas peneliti.

\section{Rancangan Analisis Data}

Data primer hasil penelitian dari pengaruh kepemimpinan, budaya organisasi, dan motivasi terhadap kinerja guru akan dianalisis secara desktriptif dan analisis verifikatif dengan menggunakan analisis korelasi, determinasi dan analisis jalur (path analysis) selanjutnya dilakukan uji t dan uji F.

\section{Hasil Penelitian}

Distribusi tanggapan responden terhadap variabel kepemimpinan menunjukkan bahwa responden berpendapat setuju. Hal ini terlihat dari data mayoritas jawaban responden berada di skala 4 sebanyak 36,4\%. Berdasarkan total skor untuk variabel Kepemimpinan sebesar 4471 dan rata-rata skor sebesar 298,1 dengan kriteria rentang skala sampel responden Kepemimpinan secara umum berada pada kriteria Setuju/Baik.

Distribusi tanggapan responden terhadap variabel budaya organisasi menunjukkan bahwa responden berpendapat setuju. Hal ini terlihat dari data mayoritas jawaban responden berada di skala 4 sebanyak 49,5\%. Jawaban variabel Budaya Organisasi (X2) berdasarkan 15 pertanyaan yang diajukan dan mendapat respon positif dari mayoritas responden dengan skor ideal sebesar 340,7 berada pada rentang skala 282,2 - 348,6 masuk kedalam kategori Setuju/Baik.

Distribusi tanggapan responden terhadap variabel motivasi menunjukkan bahwa responden berpendapat setuju. Hal ini terlihat dari data mayoritas jawaban responden berada di skala 4 sebanyak 48,1\%. Berdasarkan hasil tanggapan responden pada setiap kuesioner, diperoleh total skor untuk variabel Motivasi sebesar 2357 dan rata-rata skor sebesar 235,7 dengan kriteria rentang skala sampel responden Motivasi guru secara umum berada pada kriteria Cukup Baik.

Distribusi tanggapan responden terhadap variabel Kinerja Guru menunjukkan bahwa responden berpendapat cukup setuju. Hal ini terlihat dari data mayoritas jawaban responden berada di skala 3 sebanyak 33,6\%. Jawaban variabel variabel Kinerja Guru (X3) berdasarkan 9 pertanyaan yang diajukan dan mendapat respon positif dari mayoritas responden dengan skor ideal sebesar 291,9 berada pada rentang skala 282,2 - 348,6 masuk kedalam kategori Setuju/Baik.

Besaran koefisien korelasi diantara variabel bebas yaitu hubungan antara kepemimpinan $\left(\mathrm{X}_{1}\right)$ dengan Budaya Organisasi Guru $\left(\mathrm{X}_{2}\right)$ sebesar 0,603 yang berarti mempunyai tingkat hubungan yang kuat dan searah karena nilainya positif. Adapun besaran korelasi antara variabel Budaya Organisasi $\left(\mathrm{X}_{2}\right)$ dan Motivasi $\left(\mathrm{X}_{3}\right)$, diperoleh besaran koefisien korelasi hubungan antara Budaya Organisasi $\left(\mathrm{X}_{2}\right)$ dengan Motivasi $\left(\mathrm{X}_{3}\right)$ didapat nilai sebesar 0,632 yang berarti mempunyai tingkat hubungan yang kuat dan searah karena nilainya positif. 
Berdasarkan hasil perhitungan dan pengolahan data didapatkan koefisien jalur untuk variabel kepemimpinan $\left(\mathrm{X}_{1}\right)$, Budaya Organisasi $\left(\mathrm{X}_{2}\right)$, Motivasi $\left(\mathrm{X}_{3}\right)$ terhadap kinerja Guru (Y). Hasil analisis tersebut dapat dilihat pada tabel 1:

Tabel 1

Coefficients $^{\text {a }}$

\begin{tabular}{|c|c|c|c|c|c|}
\hline \multirow[b]{2}{*}{ Model } & \multicolumn{2}{|c|}{$\begin{array}{l}\text { Unstandardized } \\
\text { Coefficients }\end{array}$} & \multirow{2}{*}{$\frac{\begin{array}{c}\text { Standardized } \\
\text { Coefficients }\end{array}}{\text { Beta }}$} & \multirow[b]{2}{*}{$\mathrm{t}$} & \multirow[b]{2}{*}{ Sig. } \\
\hline & B & Std. Error & & & \\
\hline (Constant) & -16.403 & 3.789 & & -4.329 & .000 \\
\hline Kepemimpinan & .238 & .052 & .329 & 4.585 & .000 \\
\hline Budaya & .378 & .093 & .324 & 4.073 & .000 \\
\hline Motivasi & .477 & .096 & .369 & 4.994 & .000 \\
\hline
\end{tabular}

a. Dependent Variable: Kinerja

Sumber : Hasil pengolahan data kuesioner, SPSS, 2017

Berdasarkan Tabel di atas diperoleh koefisien jalur untuk variabel kepemimpinan $\left(\mathrm{X}_{1}\right)$ terhadap variabel kinerja Guru $(\mathrm{Y})$ yaitu sebesar $\rho_{\mathrm{YX} 1}=0,329$ sehingga diperoleh pengaruh langsung variabel kepemimpinan $\left(\mathrm{X}_{1}\right)$ terhadap kinerja Guru (Y) sebesar $\rho_{\mathrm{yx} 1}^{2}=10.8 \%$. Sedangkan pengaruh tidak langsung variabel kepemimpinan $\left(\mathrm{X}_{1}\right)$ terhadap kinerja Guru $(\mathrm{Y})$ sebesar 12,6\%. Dengan demikian pengaruh variabel kepemimpinan $\left(\mathrm{X}_{1}\right)$ terhadap kinerja Guru $(\mathrm{Y})$ adalah sebesar 23,4\%. Besarnya nilai error $(\rho y \varepsilon)=\sqrt{ }(1-$ Rsquare $)=\sqrt{ }(1-0,753)=\sqrt{ } 0.061=$ 0.247 .

Koefisien jalur untuk variabel Budaya Organisasi $\left(\mathrm{X}_{2}\right)$ terhadap variabel kinerja Guru (Y) yaitu sebesar $\rho_{\mathrm{YX} 2}=0,324$ sehingga diperoleh pengaruh langsung variabel Budaya Organisasi $\left(\mathrm{X}_{2}\right)$ terhadap kinerja Guru $(\mathrm{Y})$ sebesar $\rho_{\mathrm{yx} 2}^{2}=10,5 \%$. Sedangkan pengaruh tidak langsung variabel Budaya Organisasi $\left(\mathrm{X}_{2}\right)$ terhadap kinerja Guru (Y) sebesar $14 \%$. Dengan demikian pengaruh variabel Budaya Organisasi $\left(\mathrm{X}_{2}\right)$ terhadap kinerja Guru (Y) adalah sebesar 24,5\%.

Koefisien jalur untuk variabel Motivasi $\left(\mathrm{X}_{3}\right)$ terhadap variabel kinerja Guru (Y) yaitu sebesar $\rho_{\mathrm{YX} 3}=0,369$ sehingga diperoleh pengaruh langsung variabel Motivasi $\left(\mathrm{X}_{3}\right)$ terhadap kinerja Guru $(\mathrm{Y})$ sebesar $\rho_{\mathrm{yx} 3}^{2}=13,7 \%$. Sedangkan pengaruh tidak langsung variabel Motivasi $\left(\mathrm{X}_{3}\right)$ terhadap kinerja Guru (Y) 13,8\%. Dengan demikian pengaruh variabel Motivasi $\left(\mathrm{X}_{3}\right)$ terhadap kinerja Guru (Y) adalah sebesar 27,4\%. Hasil pengujian analisis jalur secara keseluruhan dapat digambarkan seperti yang tampak pada gambar 1 di bawah ini : 


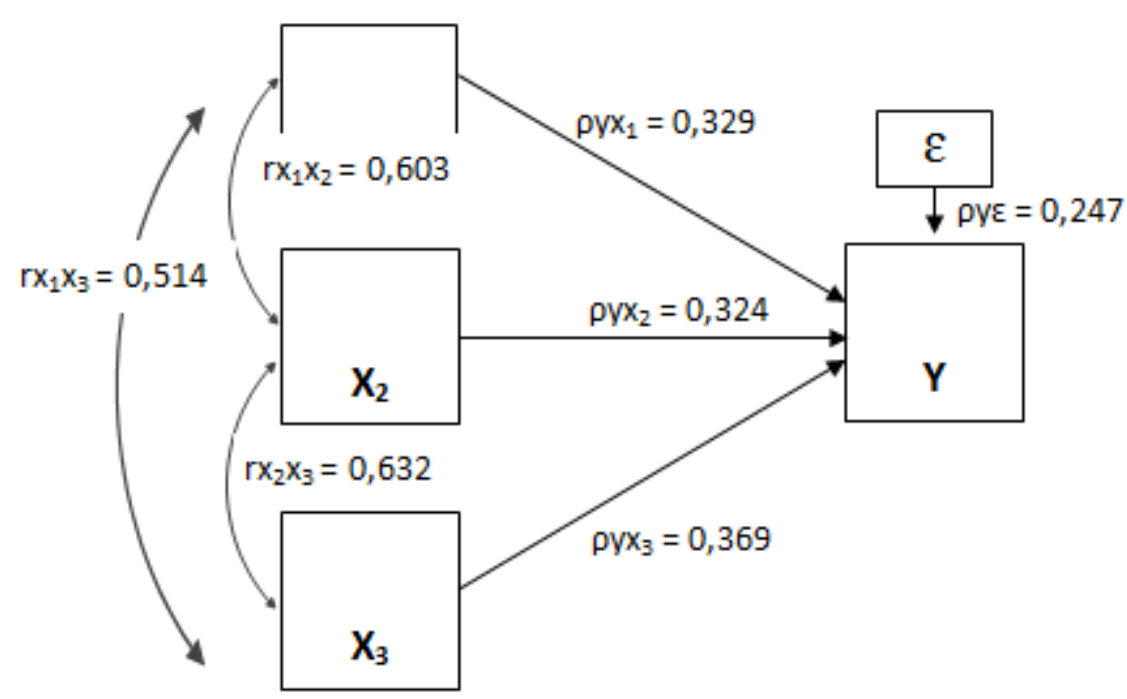

\section{Gambar 1 \\ Koefisien Jalur Kepemimpinan $\left(\mathbf{X}_{1}\right)$, Budaya Organisasi $\left(\mathbf{X}_{2}\right)$ dan Motivasi kerja $\left(\mathbf{X}_{3}\right)$ terhadap Kinerja Guru (Y)}

Berdasarkan gambar 1 dapat dilihat untuk masing-masing variabel bebas terhadap variabel terikat bahwa besaran derajat asosiatif atau koefisien jalur variabel Motivasi $\left(\mathrm{X}_{3}\right)$ lebih tinggi dibandingkan dengan variabel Budaya Organisasi $\left(\mathrm{X}_{2}\right)$ ataupun variabel Kepemimpinan $\left(\mathrm{X}_{1}\right)$ artinya Motivasi $\left(\mathrm{X}_{3}\right)$ lebih berpengaruh terhadap kinerja Guru (Y) dibandingkan variabel Budaya Organisasi $\left(\mathrm{X}_{2}\right)$ ataupun variabel Kepemimpinan $\left(\mathrm{X}_{1}\right)$. Sehingga untuk persamaan jalurnya yaitu $Y=0,329 X_{1}+0,324 X_{2}+0,369 X_{3}+0,247 \varepsilon$

Dengan demikian, pengaruh secara simultan variabel kepemimpinan $\left(\mathrm{X}_{1}\right)$, Budaya Organisasi $\left(\mathrm{X}_{2}\right)$, dan Motivasi $\left(\mathrm{X}_{3}\right)$ terhadap kinerja Guru (Y) adalah sebesar $75,3 \%$.

\section{Pembahasan Penelitian \\ Pembahasan Deskriptif}

Hasil penelitian yang telah dideskripsikan di atas, dengan mengacu pada metode yang digunakan, selanjutnya dilakukan pembahasan deskriptif atas hasil penelitian tersebut, sebagai berikut:

1. Kepemimpinan mempunyai nilai dengan total skor 4471 dengan nilai rata-rata skor 298,1, berada pada nilai rentang skala 282,2 - 348,6. Jika digambarkan dengan rentang skala berada pada rentang skala baik. Persepsi Guru mengenai kepemimpinan secara umum sudah baik. Kepala sekolah Sebagai Manager dalam membuat visi dan misi sudah dipersepsikan baik oleh para guru dengan nilai skor tertinggi dibandingkan indikator kepemimpinan lainnya yaitu sebesar 313, sedangkan skor terendah pada indikator kepala sekolah sebagai educator dalam pembinaan guru mendapat skor terendah dibanding indikator lainnya yaitu sebesar 276 . 
2. Budaya organisasi mencapai nilai dengan total skor 5.110 , dengan nilai ratarata skor 340,7 berada pada nilai rentang skala $282,2-348,6$. Jika dituangkan dalam rentang skala berada pada skala baik. Hal ini ditunjukkan dengan pilihan responden yang berada pada kategori tinggi terhadap variabel Budaya Organisasi. Artinya bahwa Budaya Organisasi sudah baik dan sesuai dengan kebutuhan dan harapan organisasi, dimana dimensi Inovasi dan keberanian mengambil resiko pada Penciptaan suasana kerja memiliki nilai skor tertinggi dibanding dimensi lainnya yaitu sebesar 357. Namun walaupun Budaya Organisasi secara umum sudah berada pada posisi baik, masih terdapat beberapa indikator yang dinilai masih rendah yaitu dimensi Berorientasi kepada hasil pada Penguasaan bidang kerja dengan nilai skor terendah dibanding dimensi lainnya yaitu sebesar 324, sehingga perlu adanya peningkatan Budaya Organisasi melalui upaya pendekatan organisasi dengan baik.

3. Motivasi mencapai nilai total skor sebesar 2.357 dan rata-rata skor sebesar 235,7 berada pada nilai rentang skala $215,8-282,2$. Skala ini menunjukan bahwa Motivasi Guru jika dituangkan pada rentang skala berada pada skala cukup baik. Artinya bahwa Motivasi guru cukup baik. Namun masih terdapat indikator Motivasi dengan skor terendah yaitu Faktor pemeliharaan pada Hubungan antar pribadi dengan jumlah nilai skor 213, sehingga indikator inilah yang menjadi permasalahan dalam organisasi yang perlu diperbaiki dan ditingkatkan.

4. Kinerja guru mencapai nilai total skor sebesar 2.604 dengan nilai rata-rata skor sebesar 291,9 berada pada nilai rentang skala 282,2 - 348,6. Skala ini menunjukan bahwa kinerja Guru jika dituangkan pada rentang skala berada pada skala baik. Artinya bahwa kinerja Guru sudah baik. Namun masih terdapat indikator kinerja guru dengan skor terendah yaitu Perencanaan Pembelajaran dan Melatih kemampuan siswa. Sehingga indikator-indikator inilah yang menjadi permasalahan dalam organisasi yang perlu diperbaiki dan ditingkatkan.

\section{Pembahasan Verifikatif}

Mengacu pada metode penelitian yang digunakan, selanjutnya berdasarkan hasil deskripsi penelitian, pembahasan hasil penelitian verifikatif dapat diuraikan sebagai berikut :

1. Korelasi kepemimpinan dengan Budaya Organisasi mempunyai nilai koefisien korelasi (r) sebesar 0,603 dan jika diinterpretasikan dengan keeratan hubungan kedua variabel ini mempunyai tingkat hubungan yang kuat (Sugiyono, 2005 : 255) dan searah karena nilainya positif. Ini menunjukan bahwa jika Kepemimpinan meningkat maka Budaya Organisasi akan meningkat. Sebaliknya jika Budaya Organisasi meningkat maka Kepemimpinan juga akan meningkat. Korelasi Budaya Organisasi dengan Motivasi mempunyai nilai koefisien korelasi (r) sebesar 0,632 dan jika diinterpretasikan dengan keeratan hubungan kedua variabel ini mempunyai tingkat hubungan yang kuat (Sugiyono, 2005 : 255) dan searah karena nilainya positif. Ini menunjukan bahwa jika Budaya Organisasi meningkat maka Motivasi akan meningkat. Sebaliknya jika Motivasi meningkat maka Budaya Organisasi juga akan meningkat. Korelasi kepemimpinan dengan Motivasi mempunyai nilai 
koefisien korelasi (r) sebesar 0,514 dan jika diinterpretasikan dengan keeratan hubungan kedua variabel ini mempunyai tingkat hubungan yang cukup kuat (Sugiyono, 2005 : 255) dan searah karena nilainya positif. Ini menunjukan bahwa jika kepemimpinan meningkat maka Motivasi juga akan meningkat. Sebaliknya jika Motivasi menurun maka kepemimpinan juga akan menurun.

2. Besaran pengaruh kepemimpinan terhadap kinerja guru mempunyai nilai koefisien determinasi sebesar 0,234 atau berpengaruh sebesar 23,4\%. Besaran pengaruh budaya organisasi terhadap kinerja guru mempunyai nilai koefisien determinasi sebesar 0,245 atau berpengaruh sebesar 24,5\%. Jadi, budaya organisasi berkontribusi secara signifikan terhadap kinerja guru. Besaran pengaruh motivasi terhadap kinerja guru mempunyai nilai koefisien determinasi sebesar 0,273 atau berpengaruh sebesar 27,3\%. Jadi, motivasi berkontribusi secara signifikan terhadap kinerja guru.

Nilai Koefisien Determinasi memiliki pengaruh secara simultan kepemimpinan, Budaya Organisasi dan Motivasi terhadap Kinerja Guru sebesar 0,753. Sehingga dapat diartikan bahwa total pengaruh kepemimpinan, budaya organisasi dan motivasi terhadap kinerja guru sebesar 0,753 atau sebesar 75, 3\%. Berdasarkan hasil penelitian ini menunjukan bahwa kepemimpinan, Budaya Organisasi dan Motivasi memiliki kontribusi terhadap kinerja Guru sebesar 75,3\% sedangkan sisanya 0,247 atau sebesar 24,7\% merupakan pengaruh kontribusi variabel lain $(\varepsilon)$ yang tidak diteliti

\section{Kesimpulan}

Berdasarkan hasil analisis data dan pembahasan yang telah dikemukakan pada bab sebelumnya, maka dalam bab ini akan dikemukakan secara garis besar mengenai kesimpulan yang diuraikan sebagai berikut :

1. Kepemimpinan kepala sekolah pada SMP Negeri se- Kecamatan Ciasem Kabupaten Subang sudah baik, hal ini dilihat dari hasil penelitian dimana variabel kepemimpinan mempunyai nilai dengan total skor 4471 dan dengan nilai rata-rata skor 298,1. Jika digambarkan dengan rentang skala berada pada rentang skala baik. Hal ini ditunjukkan dengan pilihan responden yang berada pada kategori baik terhadap variabel kepemimpinan. Terdapat skor tertinggi dari dimensi kepala sekolah sebagai manajer pada indikator kepala sekolah mampu membuat Visi dan Misi, namun persepsi pegawai masih rendah pada dimensi kepala sekolah sebagai edukator dengan indikator pembinaan Guru. Budaya Organisasi pada SMP Negeri se- Kecamatan Ciasem Kabupaten Subang sudah baik, hal ini terlihat dari hasil penelitian dimana variabel Budaya Organisasi mempunyai nilai dengan total skor 5110, dengan nilai rata-rata skor 340,7 Jika dituangkan dalam rentang skala berada pada skala baik. Terdapat nilai skor tertinggi pada Budaya Organisasi yaitu dimensi inovasi dan keberanian mengambil resiko dengan indikator penciptaan suasana kerja, sedangkan masih terdapat indikator yang dinilai masih rendah yaitu pada dimensi berorientasi pada hasi pada Indikator Penguasaan bidang pekerjaan dimana masih menempatkan beberapa guru yang tidak sesuai dengan pendidikannya. Motivasi guru di SMP Negeri se- Kecamatan Ciasem Kabupaten Subang cukup baik, hal ini terlihat dari hasil penelitian dimana motivasi guru mempunyai nilai dengan total skor 2357 dengan nilai rata-rata skor 235,7. Jika dituangkan dalam rentang skala berada pada skala Cukup 
Baik. Terdapat nilai skor jawaban responden tertinggi pada motivasi guru yaitu pada dimensi faktor motivasional dengan indikator kesempatan intuk meningkatkan karir, sedangkan nilai skor terendah terdapat pada dimensi pemeliharaan pada Indikator hubungan antar pribadi antar guru perlu diperbaiki, agar motivasi yang dimiliki masing masing guru dapat ditingkatkan dengan adanya kerjasama dari semua guru dan staf TU yang ada di sekolah SMP Negeri se Kecamatan Ciasem Kabupaten Subang. Kinerja Guru di SMP Negeri se- Kecamatan Ciasem Kabupaten Subang sudah baik, hal ini terlihat dari hasil penelitian dimana variabel Kinerja Guru mempunyai nilai dengan total skor 2627, dengan nilai rata-rata skor 291,9. Jika dituangkan dalam rentang skala berada pada skala baik. Terdapat nilai skor tertinggi pada kinerja guru pada dimensi membimbing dengan indikator membimbing siswa menjadi lebih baik, walaupun Kinerja Guru secara umum sudah berada pada posisi baik, masih terdapat beberapa indikator yang dinilai masih rendah yaitu pada dimensi mengajar beroriantasi pada Indikator perencanaan pembelajaran, dimana masih terdapat beberapa guru yang tidak membuat rencana pembelajaran pada awal ajaran baru yang disebabkan kurikulum yang setiap tahun terjadi perubahan dan ketidak mampuan guru menggunakan teknologi.

2. Korelasi kepemimpinan dengan Budaya Organisasi mempunyai nilai koefisien korelasi (r) sebesar 0,603 dan jika diinterpretasikan dengan keeratan hubungan kedua variabel ini mempunyai tingkat hubungan yang kuat dan searah karena nilainya positif. Ini menunjukkan bahwa jika kepemimpinan meningkat, maka Budaya Organisasi juga akan meningkat. Sebaliknya jika Budaya Organisasi menurun maka kepemimpinan juga akan menurun. Korelasi Budaya Organisasi dengan Motivasi mempunyai nilai koefisien korelasi (r) sebesar 0,632 dan jika diinterpretasikan dengan keeratan hubungan kedua variabel ini mempunyai tingkat hubungan yang kuat dan searah karena nilainya positif. Ini menunjukkan bahwa jika Budaya Organisasi meningkat, maka Motivasi juga akan meningkat. Sebaliknya jika Motivasi menurun, maka Budaya Organisasi juga akan menurun. Korelasi kepemimpinan dengan Motivasi mempunyai nilai koefisien korelasi (r) sebesar 0,514 dan jika diinterpretasikan dengan keeratan hubungan kedua variabel ini mempunyai tingkat hubungan yang cukup kuat dan searah karena nilainya positif. Ini menunjukkan bahwa jika kepemimpinan meningkat, maka Motivasi juga akan meningkat. Sebaliknya jika Motivasi menurun, maka kepemimpinan juga akan menurun.

3. Pada penelitian ini, besar pengaruh Kepemimpinan terhadap Kinerja Guru sebesar 32,9 \%, besar pengaruh Budaya Organisasi terhadap Kinerja Guru adalah sebesar 32,4\% dan pengaruh Motivasi terhadap Kinerja Guru adalah sebesar 36,9\%. Berdasarkan pengolahan data tersebut menunjukkan bahwa nilai $36,9 \%>32,9 \%>32,4 \%$. Hal ini menunjukkan bahwa peran Motivasi lebih besar dan dominan memberikan kontribusi terhadap Kinerja Guru dibandingkan Kepemimpinan dan Budaya Organisasi.

4. Hasil pengujian secara simultan menunjukkan bahwa terdapat pengaruh yang signifikan antara kepemimpinan, budaya organisasi dan motivasi terhadap kinerja Guru SMP Negeri se- Kecamatan Ciasem Kabupaten Subang. Adapun besarnya R Square sebesar 75,3\% menunjukkan bahwa Kinerja Guru dipengaruhi oleh kepemimpinan, budaya organisasi dan motivasi. Sedangkan 
sisanya $24,7 \%$ dipengaruhi oleh variabel lain yang tidak diujikan dalam penelitian ini.

\section{Saran}

Berdasarkan implikasi penelitian yang diatas, dapat disampaikan saransaran praktis untuk meningkatkan kinerja guru, sebagai berikut :

1. Nilai yang masih rendah pada kepemimpinan yaitu Kepala sekolah sebagai edukator dengan indikator pembinaan guru. Kepala sekolah sebagai edukator harus mampu melakukan pembinaan kepada bawahan khususnya guru, tidak hanya dilakukan secara menyeluruh tetapi pembinaan tersebut bisa dilakukan secara personal, agar semua guru merasakan dihargai dan diperhatikan tanpa merasa dibedakan satu dengan lainnya.

2. Nilai yang masih rendah pada budaya organisasi yaitu dimensi berorientasi pada tim dengan dimensin kerja sama dengan orang lain.Budaya yang ada dilingkungan sekolah belum mampu merangsang masing masing guru membentuk kerjasama satu dengan lainnya, hal ini terlihat masih ditemukan benturan dari tim yang dibentuk kepala sekolah, dimana kepala sekolah dalam pembagian tim kerja lebih melihat senioritas dibandingkan kinerja yang dihasilkan oleh bawahannya/guru.Untuk itu kepala sekolah memberi kesempatan untuk guru yang muda/ yang kreatif atau terjadinya regenerasi tim kerja setiap periodenya agar tidak terjadi kejenuhan didalam organisasi sekolah.

3. Nilai yang masih rendah pada motivasi yaitu pada dimensi pemeliharaan pada indikator hubungan antar pribadi guru perlu diperbaiki, agar motivasi yang dimiliki masing masing guru dapat ditingkatkan dengan adanya kejasama dari semua guru dan staf TU tidak hanya berdasarkan senioritas dan yunioritas yang ada di sekolah SMP Negeri se kecamatan Ciasem Kabupaten Subang. Peran Kepala Sekolah untuk dapat memelihara hubungan antar pribadi guru senior dengan guru yunior, agar tercipta kerjasama antara guru senior dengan guru yunior atau guru PNS dengan guru Non PNS

4. Nilai yang masih rendah pada kinerja guru yaitu pada dimensi mengajar berorientasi pada indikator perencanaan pembelajaran dimana masih menempatkan beberapa guru yang tidak atau belum mampu membuat rencana pembelajaran pada awal ajaran baru yang di sebabkan kurikulum yang setiap tahun terjadi perubahan dan ketidak mampuan guru menggunakan teknologi. Kepala sekolah mengirim para guru melakukan pelatihan dalam meningkatkan kinerja guru khususnya dalam penguasaan teknologi, agar guru mampu meningkatkan penguasaan teknologi.

5. Motivasi sangat mempengaruhi kinerja guru, oleh sebab itu indikator-indikator motivasi yang sudah baik harus dipertahankan, sedangkan setiap variabel yang mempengaruhi lainnya, baik kepemimpinan dan budaya organisasi harus lebih ditingkatkan dalam setiap kesempatan sehingga selalu dapat mempengaruhi kinerja guru secara berkesinambungan. Karena ilmu pengetahuan selalu berubah, variabel kepemimpinan dan budaya organisasi membutuhkan pihak lain untuk mewujudkan tujuan yang di capai, maka peran kepala sekolah yang terlibat langsung dalam pembinaan kinerja guru harus bekerja dalam suatu tim dalam pencapaian kurikulum yang bulat,utuh dan tuntas. 
6. Motivasi mempengaruhi peningkatan kinerja guru, untuk itu motivasi perlu ditingkatkan oleh setiap guru, karena motivasi sebagai perubahan energy dalam diri seseorang di tandai dengan munculnya"felling" dan didahului dengan tanggapan terhadap seseorang guru sangat dibutuhkan jika kita ingin menjadi guru profesional dan kinerja semakin baik. Motivasi dapat ditingkatkan dengan cara: (1) berusaha dengan sungguh sungguh untuk meningkatkan prestasi dengan mempelajari berbagai sumber bacaan untuk meningkatkan pengetahuan dan keterampilan, (ii) membina hubungan sosial dan kerjasama yang lebih baik dengan atasan dan rekan guru lainnya, (iii) berusaha meningkatkan keahlian dan kemampuan memecahkan masalah,(iv) menyelesaikan pekerjaan dengan penuh tanggungjawab. (v) tidak menunda pekerjaan, (vi) memperbaiki hasil kerja agar mendapatkan pengakuan dari atasan dan guru lainnya,(vii) memberikan insentif dan penghargaan bagi guru yang berprestasi, dan (viii) membangun kondisi kerja yang kondusif

7. Dinas Pendidikan diharapkan memperbaiki kebijakan dan sistem kepemimpinan agar lebih dirasakan layak dan adil bagi para guru, meningkatkan budaya organisasi para guru terhadap organisasinya serta mendorong para guru untuk meningkatkan motivasinya dalam menjalankan tugas, sehingga kinerja guru dapat ditingkatkan dalam mewujudkan guru yang profesional

\section{Daftar Pustaka}

Arikunto, S, 2006,'Prosedur Penelitian, Suatu Pendekatan Praktik", Edisi VI, Rhineka Cipta, Yogyakarta

Kerlinger, Fred N., 2004. “Asas-Asas Penelitian Behavioral”, Universitas Gadjahmada, Yogyakarta.

Gomes, Faustino Cardoso, 2003, "Manajemen Sumber Daya Manusia", ANDI, Yogyakarta.

Gibson, Ivancevich Dan Donelly, 2003," Organisasi”, Edisi Kedelapan, Jilid 2, Binarupa Aksara, Jakarta

Handoko, T. Hani, 2001,"Manajemen Personalia \& Sumberdaya Manusia”, Cetakan Ke-15, BPFE-Yogyakarta, Yogyakarta.

Hasibuan, Malayu S.P. , 2014," Manajemen Sumber Daya Manusia (Edisi Revisi)", Penerbit Bumi Aksar, Jakarta

Hasibuan, Malayu S.P., 2001,"Manajemen Sumber Daya Manusia:Pengertian Dasar, Pengertian, Dan Masalah", PT. Toko Gunung Agung, Jakarta

Hasibuan, Malayu S.P., 2003,'Organisasi Dan Motivasi: Dasar Peningkatan Produktivitas", Bumi Aksara, Jakarta

Hasibuan, Malayu S.P., 2003, "Manajemen Sumber Daya Manusia”, Edisi Revisi, Cetakan Keenam, Penerbit Bumi Aksara, Jakarta

Hasibuan, Malayu S.P., 2009,"Manajemen Sumber Daya Manusia Edisi Revisi" ,PT Bumi Aksara, Jakarta

Yulius Eka Agung Seputra, 2014," Manajemen Dan Perilaku Organisasi”, Penerbit Graha Ilmu

Manullang, M., 2005, “Dasar-Dasar Manajemen”, Gadjah Mada University Press PO BOX 14, Bulaksumur, Yogyakarta

Mangkunegara, Anwar Prabu, 2008," Manajemen Sumber Daya Manusia Perusahaan “, PT Remaja Rosdakarya, Bandung 
Mangkunegara, 2009,"Manajemen Sumber Daya Manusia Perusahaan”, Cetakan Keenam, PT. Remaja Rosdakarya, Bandung

Mangkunegara, Anwar Prabu, 2009," Manajemen Sumber Daya Manusia Perusahaan", PT Remaja Rosdakarya Offset, Bandung

Nur Indriantoro, 2002,"Metodelogi Penelitian Bisnis Untuk Akuntansi Dan Manajemen", Cetakan 2, BPFE-Yogyakarta, Yogyakarta

Panggabean, Mutiara, 2007,"Manajemn Sumber Daya Manusia", Ghalia Indonesia, Bogor

Rivai, Veithzal Dan Basri, Ahmad Fawzi Mohd., 2005,'Performance Apraisal", Raja Grafindo Persada, Jakarta

Rivai, Veithzal Dan Sagala, Ella Jauvani, 2010,"Manajemen Sumber Daya Manusia Untuk Perusahaan Dari Teori Ke Praktik", PT Raja Grafindo, Jakarta

Rivai, Veithzal, 2014,"Manajemen Sumber Daya Manusia Untuk Perusahaan", Edisi Ke 6, PT. Raja Grafindo Persada, Depok

Robbins, Stephen P, 2008," Perilaku Organisasi”, Edisi 12, Salemba Empat, Jakarta

Sedarmayanti, 2007,"Sumber Daya Manusia Dan Produktivitas Kerja”, Penerbit Mandar Maju, Bandung

Sedarmayanti, 2010, "Ma najemen Sumber Daya Manusia Reformasi Birokrasi Dan Manajemen Pegawai Negeri Sipil”, PT. Refka Aditama, Bandung

Sedarmayanti, 2007, “Sumber Daya Manusia Dan Produktivitas Kerja”, Penerbit Mandar Maju, Bandung

Siswanto,2005,'Pengantar Manajemen", Penerbit Bumi Aksara, Jakarta

Sugiyono, 2007, “Memahami Penelitian Kualitatif”, Penerbit CV. Alfabeta, Bandung

Sugiyono, 2005, "Memahami Penelitian Kualitatif", Penerbit CV. Alfabeta, Bandung

Sugiyono, 2008, "Statistika Untuk Penelitian”, Penerbit CV. Alfabeta, Bandung

Sugiyono, 2014," Metode Penelitian Manajemen", Penerbit CV. Alfabeta, Bandung

Sutarto, 2006,"Dasar-Dasar Kepemimpinan Administrasi”, Gajah Mada Universitas, Yogjakarta

Thoha, Miftah, 2006,"Kepemimpinan Dalam Manajemen", PT. Rajagrafindo Persada, Jakarta

Tubagus Achmad Darodjat, 2015,"Konsep-Konsep Dasar Manajemen Personalia Masa Kini", Penerbit Refika Aditama

Umar Husein, 2005," Riset Sumber Daya Manusia Dalam Organisasi”, Penerbit PT. Gramedia Pustaka Utama, Jakarta

Wibowo, 2010, "Manajemen Kinerja”, Edisi Ketiga, Rajawali Pers, Jakarta

Wahjosumidjo, (2010),"Kepemimpinan Kepala Sekolah, Tinjauan Teoretik Dan Permasalahannya", Raja Grapindo Persada, Jakarta

Wirawan, 2007," Budaya Dan Iklim Organisasi”, Salemba Empat, Jakarta

Undang-Undang Republik Indonesia Nomor 14 Tahun 2005 Tentang Guru Dan Dosen. 